\title{
VÝVOJ CENY VODNÉHO A STOČNÉHO V ČESKÉ REPUBLICE
}

\author{
DEVELOPMENT OF THE PRICE OF WATER AND SEWER IN THE \\ CZECH REPUBLIC
}

\author{
Aneta Oblouková, ${ }^{*}$ \\ "a.obloukova@seznam.cz \\ ${ }^{1}$ Vysoké učení technické v Brně, Fakulta stavební, Veveří 331/95, 60200 Brno
}

\begin{abstract}
Abstrakt
Článek se zabývá problematikou vodného a stočného za posledních 10 let. Výzkum je zaměřen jak na celou Českou republiku, tak i na jednotlivé kraje v ní. Výzkum je založen na sběru dat. Data byly získány z internetového portálu eAGRI.cz. Cílem článku je popsat vývoj vodného a stočného v České republice v průběhu posledních 10 let (20102019). Nejprve zanalyzovat průměrné vodné a stočné ČR ve sledovaném období, poté definovat průměrné vodné a stočné pro jednotlivé kraje. Pro zhodnocení dat je zvolena metodika horizontální analýzy. Z provedené analýzy je zrrejmé, že má průměrná cena vodného a stočného v ČR neustále rostoucí tendenci, kterou lze očekávat i v dalších letech.
\end{abstract}

\section{Klíčová slova}

Vodné, stočné, horizontální analýza, průměrná cena

\begin{abstract}
This article is about problems with prices of water and sewer for last ten years. This research is not only focused on the entire Czech Republic but also on individual regions of our country. Investigation is strictly based on data collection, and all of them were taken from internet served eAGRI.cz. Most of content is aimed to report prices of water and sewer for last ten years (2010-2019). First of all, analyse average prices of water and sewer of all of the Czech Republic and then for separate districts. For this investigation is chosen horizontal analysis method. At the end of research we can clearly see, that prices of water and sewer are constantly growing, and we can expect this tendency to continue.
\end{abstract}

Key words

Water, sewer, horizontal analysis, average price

\section{1 ÚVOD}

Problematika týkající se vody má ve světě čím dál větší význam a je velmi diskutovaným tématem dnešní doby. Kvůli globálnímu oteplování a nedostatku srážek dochází ke značným úbytkům vody. V České republice dochází k vysychání studen a podzemních zdrojů vody. Nejen globální oteplování však v České republice přispívá ke ztrátám podzemních vod.

Před 20 lety ještě nikdo nepřemýšlel nad tím, zda je na Zemi dostatek vody, jestli s ní je nakládáno hospodárně, zda bude dostatek vody i pro budoucí generace obyvatelstva. Dnes snad každý vnímá situaci a změny v př́rodě, které nastávají. Je potřeba si tedy klást otázky, jak s vodou hospodárně nakládat, jak vodu chránit a neznečišt'ovat, nebo co pro ochranu vodních zdrojů lze dělat.

Nedostatek vody však není jediným a hlavním faktorem, který ročně navyšuje cenu vodného a stočného v ČR. Pitná voda a voda odvedená kanalizací je totiž zařazena do seznamu zboží s regulovanými cenami, který každý rok vydává podle zákona o cenách Ministerstvo financí ČR a je dostupný v Cenovém věstníku. Do ceny vodného a stočného lze tedy zakalkulovat pouze ekonomicky oprávněné náklady na pořízení, zpracování a oběh zboží, které je doloženo z účetnictví, dále pak daň, přiměřený zisk (10-20\%), př́ípadně uplatněné clo podle jiných právních předpisů, není-li stanoveno jinak. Zjednodušeně lze říci, že cena vody se skládá z vodného, tedy z veškerých nákladů, které jsou spojené s výrobou a distribucí pitné vody, a ze stočného, které zahrnuje náklady na odvod 
a čištění odpadních vod. Tímto způsobem cenové regulace jsou nastavena základní pravidla pro stanovení ceny, část zodpovědnosti je však ponechána pro jednotlivé vlastníky vodovodů a kanalizací (VaK).

Kalkulace cen je definována přímo ve Vyhlášce č. 450/2009 Sb., kterou se provádí zákon č. 526/1990 Sb. V § 1 odst. 2 je řečeno, že kalkulace ceny podle $\S 11$ odst. 1 písm. b) zákona o cenách se zpracovává ve struktuře uvedené v Př́loze č. 1 k této vyhlášce. Dále je v témže paragrafu odst. 4 řečeno, že kalkulace se sestavuje na jednotkové množství prodávaného zboží a vychází z nákladů, objemu zisku a množství prodeje zboží pro daný kalendářní rok. Př́iloha č. 1 k Vyhlášce č. 450/2009 Sb. Určuje minimální rozsah položek kalkulace cen podléhající věcnému usměrňování ceny, kterými jsou přímý materiál, přímé mzdy, ostatní přímé náklady, nepř́mé náklady, výrobní režie, správní režie, odpisy, u pronajatého majetku výše nájemného, ostatní náklady, zisk, v neposlední řadě cena celkem.

Podle internetového serveru Eagri.cz a Českého statistického úřadu cena vody neustále roste. Zatímco v roce 2010 byla cena pitné vody $29,10 \mathrm{Kč} / \mathrm{m}^{3}$ bez DPH a cena stočného $26,30 \mathrm{~K} \breve{c} / \mathrm{m}^{3}$ bez DPH, v roce 2020 cena pitné vody vzrostla na $41,40 \mathrm{Kč} / \mathrm{m}^{3}$ bez DPH, cena stočného vzrostla na $36,50 \mathrm{Kč} / \mathrm{m}^{3}$ bez DPH. Současný rok 2021 imponuje vyšším nárůstem ceny vodného a stočného. Vodárenské společnosti to přisuzují rostoucím nákladům a nutností investovat do infrastruktury. Na kalkulaci ceny vody se ale také podepsala pandemie koronaviru.

Cílem tohoto článku je provést analýzu vývoje cen vodného a stočného ČR. Jako zdroj dat byl zvolen resortní portál Ministerstva zemědělství (MZe) eAGRI.cz. Na tomto serveru jsou k nalezení základní informace a dokumenty MZe. Poslední vydaná publikace je za rok 2019, která byla vydána koncem roku 2020. Publikace 2020 lze tedy předpokládat koncem roku 2021. Výzkum byl proveden v časovém horizontu 10 let, tedy od roku 2010 do roku 2019. Pro zhodnocení meziročních nárůstů nebo poklesů cen vodného a stočného byla zvolena metodika horizontální analýzy.

\section{LITERÁRNÍ PŘEHLED/POPIS SOUČASNÉHO STAVU}

Základní zdroj pro dosažení výstupů tohoto článku byl internetový portál eAGRI.cz. Hlavní ideou webového portálu bylo vytvořit jeden centrální př́stupový bod $\mathrm{k}$ informačním zdrojům Ministerstva zemědělství a jeho podřízených organizací [1]. Pro relevantnost a ověření dat byl využit Český statistický úřad (ČSÚ). Je to ústřední orgán státní správy České republiky, který byl zřízen již v roce 1969 a jako hlavní orgán statistické služby koordinuje sběr a zpracování statistických údajů, které provádějí jednotlivá ministerstva [2].

Kalkulace ceny vody je definována ve vyhlášce č. 450/2009 Sb., kterou se provádí zákon č. 526/1990 Sb. [3]. Cena jako taková je definována v zákoně č. 526/1990 Sb., o cenách, ve znění pozdějších předpisů [4]. Základní pojmy, které se týkají vodovodů a kanalizací vymezuje zákon č. 274/2001 Sb., o vodovodech a kanalizacích. Upravuje také vztahy, které se týkají rozvoje, výstavby nebo provozu vodovodů a kanalizací sloužících veřejné potřebě, přípojek na ně, také působnost orgánů územních samosprávných celků a správních úřadů na tomto celku. Ve Vyhlášce č. 48/2014 Sb., kterou se mění vyhláška č. 428/2001 Sb., kterou se provádí zákon č. 274/2001 Sb., o vodovodech a kanalizacích pro veřejnou potřebu a o změně některých zákonů (zákon o vodovodech a kanalizacích), ve znění pozdějších předpisů je v Příloze č. 19 uveden podrobnější výpočet (kalkulace) cen pro vodné a stočné pro kalendářní rok [5], [6].

Jak již bylo zmíněno v úvodu, voda se stává nedostatkovým zbožím, je třeba její užívání regulovat. Neustálým rostoucím ekonomickým růstem, tlakem obyvatel a současnými i budoucími změnami klimatu je stále zřetelnější, že je vodu nutno považovat za vzácný a cenný zdroj, kterým by se nemělo plýtvat. Efektivní využívání vodního zdroje vyžaduje internalizaci všech nákladů do ceny vody, včetně nákladů na životní prostředí a zdroje [7]. Snižováním spotřeby vody a snižováním ztrát vody ve vodovodním systému se v roce 2017 zabývali Tabesh Massoud a Beigi Soheila [8].

Pro plánování a řízení vodovodního systému je také důležité znát a předpovídat poptávku po vodě. Tato myšlenka byla zkoumána v Los Angeles v Kalifornii. Výsledky ukázaly, že jakýkoli nárůst populace významně sníží pravděpodobnost dosažení cíle poptávky po vodě. V rámci př́ípravy na zvýšenou poptávku po vodě musí Los Angeles rozšírit své iniciativy na ochranu přírody a zvýšit místní dodávky vody, jako je zachycování dešt’ové vody, recyklování vody a rozšiřování skladování podzemní vody a další. Tato studie je nová $\mathrm{v}$ analýze toho, jak mohou předpovídané scénáře populačního růstu, změny klimatu, ceny a metody ochrany ovlivnit poptávku po vodě v Los Angeles. Př́istup k modelování v této studii mohou využít i jiná města k pochopení budoucnosti poptávky po vodě v oblastech s nedostatkem vody [9].

Otázkou optimální ceny vody se v roce 2020 ve svém článku zabýval Yasov Tsur. Nejprve byla prezentována analýza v kontextu komplexní vodní ekonomiky s důrazem na kompromisy mezi využíváním vody při poskytování ekosystémových služeb a jinými způsoby využití. Analýza rozlišuje dva typy vody v životním prostředí, což se ukázalo, že má důležité politické důsledky. První je dopravovaná voda, tedy voda dopravovaná z vodních zdrojů do různých environmentálních lokalit. Druhá je voda proudová. Týká se přírodní vody, která by mohla být odkloněna nebo extrahována, ale je ponechána v př́rodním stavu, aby se vylepšily ekosystémové služby. Za proudovou vodu jsou považovány zvodnělé vrstvy, jezera, potoky, řeky nebo ústí řek. Ukázalo se, že regulace 
těchto dvou druhů vody v životním prostředí se značně liší. Alokaci vody v proudu lze realizovat správným začleněním (mezní) hodnoty proudu vody do stínové (prrírodní) ceny prírodní vody. Alokace přepravované environmentální vody vyžaduje kombinaci kvót a cen. Tyto poznatky byly demonstrovány na př́kladu založeném na izraelské vodní ekonomice [10]. I spousta dalších zahraničních autorů se ve svých článcích zabývali možnostmi, jak stanovit efektivní cenu vody a cenou vody obecně [11], [12], [13].

\section{METODIKA}

Základní metodika, která byla zvolena pro popis vývoje vodného a stočného České republiky a jednotlivých krajů, se nazývá horizontální analýza. Jedná se o jednu ze základních metod finanční analýzy. Finanční analýza slouží k posouzení finanční výkonnosti firmy a zhodnocuje finanční pozici firmy. Pracuje s údaji získanými z výkazů účetní závěrky. Výstupy slouží primárně pro taktické a strategické rozhodování o investicích a financování, pro reporting vlastníkům, věřitelům a dalším zainteresovaným stranám. Podstatou analýzy je výpočet ukazatelů (elementární, poměrové, souhrnné), které mají dobrou vypovídací schopnost vzhledem ke zkoumané ekonomické realitě. Mezi elementární ukazatele se řadí horizontální a vertikální analýza. Vertikální analýza popisuje zastoupení jednotlivých položek vůči celku. Je vyjádřena absolutním číslem nebo v procentech. Pro daný výzkum však není vhodná. Druhým elementárním ukazatelem je horizontální analýza, která popisuje meziroční změnu položek $\mathrm{v}$ absolutních hodnotách nebo $\mathrm{v}$ procentech a říká, jak se dané položky změnily oproti předešlému roku. Jinými slovy jde o horizontální, tj. řádkové porovnání absolutních nebo relativních změn položek daných výkazů v časové posloupnosti. Je vhodným ukazatelem pro stanovení meziroční změny (nárůstu nebo poklesu) průměrné ceny vodného a stočného ČR v procentech. Horizontální analýza se vypočítá podle vztahu:

$$
\text { Horizontální analýza }=\frac{\left(\text { ukazatel }_{t}-\text { ukazatel }_{t-1}\right)}{\text { ukazatel }_{t-1}} * 100, \quad[\%]
$$

kde ukazatel $_{t}$ je cena vodného a stočného ve sledovaném roce, ukazatel $_{t-1}$ je cena vodného a stočného $\mathrm{v}$ roce předchozím.

\section{VÝSLEDKY}

Veškeré výstupy uvedené níže byly zpracovány na základě postupných kroků, a to sběru dat, zpracováním dat a jejich vyhodnocením za pomocí MS Excel.

V níže uvedené tabulce je znázorněn vývoj průměrné ceny vodného a stočného České republiky (viz Tab. 1) v časovém horizontu 10 let (2010-2019), také je publikován i vývoj pro jednotlivé kraje ČR (viz Tab. 3). Dané hodnoty byly sesbírány z internetového serveru eAGRI.cz.

Na základě vzorce uvedeného v metodologii tohoto článku byl stanoven procentuální meziroční nárůst nebo pokles průměrné ceny vodného a stočného ve stanovených letech pro celou ČR (viz Tab. 2). Poslední tabulka této kapitoly (Tab. 4) popisuje procentuální meziroční nárůst nebo pokles průměrné ceny vodného a stočného ve stanovených letech pro jednotlivé kraje ČR.

Tab. 1 Průměrné vodné a stočné České republiky v Kč $/ \mathrm{m}^{3}$ bez DPH.

\begin{tabular}{ccccccccccc}
\hline Ukazatel & $\mathbf{2 0 1 0}$ & $\mathbf{2 0 1 1}$ & $\mathbf{2 0 1 2}$ & $\mathbf{2 0 1 3}$ & $\mathbf{2 0 1 4}$ & $\mathbf{2 0 1 5}$ & $\mathbf{2 0 1 6}$ & $\mathbf{2 0 1 7}$ & $\mathbf{2 0 1 8}$ & $\mathbf{2 0 1 9}$ \\
\hline Vodné & 29,10 & 30,80 & 32,70 & 33,70 & 34,80 & 35,60 & 36,70 & 37,20 & 38,10 & 39,30 \\
Stočné & 26,30 & 27,90 & 29,60 & 29,20 & 29,80 & 30,70 & 32,10 & 32,80 & 33,40 & 34,70 \\
Celkem & 55,40 & 58,70 & 62,30 & 62,90 & 64,60 & 66,30 & 68,80 & 70,00 & 71,50 & 74,00 \\
\hline
\end{tabular}

Tab. 2 Horizontální analýza - meziroční změna průměrného vodného a stočného v České republice v \%.

\begin{tabular}{|c|c|c|c|c|c|c|c|c|c|}
\hline Ukazatel & $\begin{array}{c}2010- \\
2011\end{array}$ & $\begin{array}{l}\text { 2011- } \\
2012\end{array}$ & $\begin{array}{c}2012- \\
2013\end{array}$ & $\begin{array}{c}2013- \\
2014\end{array}$ & $\begin{array}{c}2014- \\
2015\end{array}$ & $\begin{array}{l}2015- \\
2016\end{array}$ & $\begin{array}{c}2016- \\
2017\end{array}$ & $\begin{array}{c}2017- \\
2018\end{array}$ & $\begin{array}{c}2018- \\
2019\end{array}$ \\
\hline Vodné & 5,84 & 6,17 & 3,06 & 3,26 & 2,30 & 3,09 & 1,36 & 2,42 & 3,15 \\
\hline Stočné & 6,08 & 6,09 & $-1,35$ & 2,05 & 3,02 & 4,56 & 2,18 & 1,83 & 3,89 \\
\hline Celkem & 5,96 & 6,13 & 0,96 & 2,70 & 2,63 & 3,77 & 1,74 & 2,14 & 3,50 \\
\hline
\end{tabular}


Tab. 3 Průměrné vodné a stočné v jednotlivých krajích ČR v Kč $/ \mathrm{m}^{3}$ bez DPH.

\begin{tabular}{|c|c|c|c|c|c|c|c|c|c|c|}
\hline Kraj & 2010 & 2011 & 2012 & 2013 & 2014 & 2015 & 2016 & 2017 & 2018 & 2019 \\
\hline $\begin{array}{l}\text { Hl. město } \\
\text { Praha }\end{array}$ & 56,20 & 59,30 & 64,90 & 65,30 & 66,10 & 67,20 & 68,70 & 72,40 & 72,90 & 74,40 \\
\hline Středočeský & 59,50 & 58,60 & 62,50 & 63,50 & 66,10 & 68,60 & 69,20 & 70,30 & 71,50 & 72,70 \\
\hline Jihočeský & 54,60 & 58,60 & 60,40 & 62,10 & 62,90 & 64,00 & 63,60 & 64,00 & 64,90 & 65,00 \\
\hline Plzeňský & 47,00 & 54,80 & 56,80 & 57,10 & 58,30 & 57,80 & 62,10 & 64,20 & 64,80 & 65,10 \\
\hline $\begin{array}{l}\text { Karlo- } \\
\text { varský }\end{array}$ & 59,40 & 63,10 & 66,50 & 66,80 & 68,10 & 68,00 & 68,50 & 70,40 & 70,70 & 71,20 \\
\hline Ústecký & 67,00 & 72,20 & 75,90 & 76,40 & 79,30 & 82,50 & 83,00 & 84,40 & 84,80 & 84,80 \\
\hline Liberecký & 66,40 & 70,40 & 76,90 & 74,40 & 77,50 & 80,20 & 82,60 & 84,10 & 84,60 & 84,90 \\
\hline $\begin{array}{l}\text { Králové- } \\
\text { hradecký }\end{array}$ & 56,70 & 58,50 & 60,40 & 62,50 & 63,60 & 65,20 & 66,80 & 67,30 & 67,70 & 67,80 \\
\hline Pardubický & 57,10 & 60,60 & 62,50 & 62,90 & 64,30 & 65,10 & 66,00 & 66,60 & 67,60 & 68,00 \\
\hline Vysočina & 50,00 & 51,30 & 54,30 & 56,90 & 58,50 & 60,30 & 61,00 & 61,70 & 62,60 & 63,90 \\
\hline $\begin{array}{c}\text { Jihomo- } \\
\text { ravský }\end{array}$ & 54,60 & 57,00 & 59,70 & 59,60 & 62,20 & 64,90 & 65,90 & 66,70 & 66,80 & 67,10 \\
\hline Olomoucký & 50,00 & 54,00 & 58,30 & 59,00 & 59,90 & 61,10 & 61,40 & 63,10 & 63,50 & 63,80 \\
\hline Zlínský & 57,30 & 59,50 & 63,20 & 61,90 & 63,20 & 63,80 & 64,50 & 65,20 & 65,30 & 65,60 \\
\hline $\begin{array}{c}\text { Moravsko- } \\
\text { slezský }\end{array}$ & 56,49 & 54,10 & 58,00 & 58,40 & 60,60 & 62,50 & 63,40 & 63,80 & 64,20 & 65,00 \\
\hline
\end{tabular}

Tab. 4 Horizontální analýza - meziroční změna průměrného vodného a stočného v jednotlivých krajích ČR v \%.

\begin{tabular}{|c|c|c|c|c|c|c|c|c|c|}
\hline Kraj & $\begin{array}{c}2010- \\
2011 \\
\end{array}$ & $\begin{array}{l}2011- \\
2012 \\
\end{array}$ & $\begin{array}{l}2012- \\
2013 \\
\end{array}$ & $\begin{array}{l}2013- \\
2014 \\
\end{array}$ & $\begin{array}{l}2014- \\
2015 \\
\end{array}$ & $\begin{array}{l}2015- \\
2016\end{array}$ & $\begin{array}{l}2016- \\
2017 \\
\end{array}$ & $\begin{array}{l}2017- \\
2018 \\
\end{array}$ & $\begin{array}{l}2018- \\
2019 \\
\end{array}$ \\
\hline $\begin{array}{l}\text { Hl. město } \\
\text { Praha }\end{array}$ & 5,52 & 9,44 & 0,62 & 1,23 & 1,66 & 2,23 & 5,39 & 0,69 & 2,06 \\
\hline Středočeský & $-1,51$ & 6,66 & 1,60 & 4,09 & 3,78 & 0,87 & 1,59 & 1,71 & 1,68 \\
\hline Jihočeský & 7,33 & 3,07 & 2,81 & 1,29 & 1,75 & $-0,63$ & 0,63 & 1,41 & 0,15 \\
\hline Plzeňský & 16,60 & 3,65 & 0,53 & 2,10 & $-0,86$ & 7,44 & 3,38 & 0,93 & 0,46 \\
\hline $\begin{array}{l}\text { Karlo- } \\
\text { varský }\end{array}$ & 6,23 & 5,39 & 0,45 & 1,95 & $-0,15$ & 0,74 & 2,77 & 0,43 & 0,71 \\
\hline Ústecký & 7,76 & 5,12 & 0,66 & 3,80 & 4,04 & 0,61 & 1,69 & 0,47 & 0,00 \\
\hline Liberecký & 6,02 & 9,23 & $-3,25$ & 4,17 & 3,48 & 2,99 & 1,82 & 0,59 & 0,35 \\
\hline $\begin{array}{l}\text { Králové- } \\
\text { hradecký }\end{array}$ & 3,17 & 3,25 & 3,48 & 1,76 & 2,52 & 2,45 & 0,75 & 0,59 & 0,15 \\
\hline Pardubický & 6,13 & 3,14 & 0,64 & 2,23 & 1,24 & 1,38 & 0,91 & 1,50 & 0,59 \\
\hline Vysočina & 2,60 & 5,85 & 4,79 & 2,81 & 3,08 & 1,16 & 1,15 & 1,46 & 2,08 \\
\hline $\begin{array}{c}\text { Jihomo- } \\
\text { ravský }\end{array}$ & 4,40 & 4,74 & $-0,17$ & 4,36 & 4,34 & 1,54 & 1,21 & 0,15 & 0,45 \\
\hline Olomoucký & 8,00 & 7,96 & 1,20 & 1,53 & 2,00 & 0,49 & 2,77 & 0,63 & 0,47 \\
\hline Zlínský & 3,84 & 6,22 & $-2,06$ & 2,10 & 0,95 & 1,10 & 1,09 & 0,15 & 0,46 \\
\hline $\begin{array}{c}\text { Moravsko- } \\
\text { slezský }\end{array}$ & $-4,23$ & 7,21 & 0,69 & 3,77 & 3,14 & 1,44 & 0,63 & 0,63 & 1,25 \\
\hline
\end{tabular}

\section{DISKUZE}

Jak je patrné z dílčích výsledků v předchozí kapitole, za celé sledované období průměrná cena vodného vzrostla o $10,2 \mathrm{Kč} / \mathrm{m}^{3}$ bez DPH a průměrná cena stočného se navýšila o $8,4 \mathrm{Kč} / \mathrm{m}^{3}$ bez $\mathrm{DPH}$. $\mathrm{K}$ nejvyššímu nárůstu 
průměrné ceny vodného a stočného došlo mezi lety 2011-2012, celkem o 6,13 \%. Průměrně cena vodného a stočného ČR ve sledovaném období meziročně rostla o $3,28 \%$.

Z Tab. 3 vyplývá, že nejdražší průměrné vodné a stočné měl ve sledovaném období Ústecký kraj, dále pak kraj Liberecký. Nejlevnější kraj průměrného vodného a stočného pro sledované období nelze stanovit, v průběhu let se situace měnila, v letech 2010, 2014 a 2015 se jednalo o Plzeňský kraj, v časových obdobích 2011-2013 a 2016-2018 kraj Vysočina a v roce 2019 v kraji Olomouckém.

Nejvyšší průměrná cena pro vodné v roce 2019 byla v kraji Libereckém, kde dosáhla hodnoty 44,80 Kč $/ \mathrm{m}^{3}$. V poměru s celorepublikovým průměrem tak byla vyšší o $14,0 \%$. Nejvyšší průměrná cena pro stočné byla rovněž v kraji Libereckém, která při výši 42,90 Kč/m³ byla o 23,6 \% vyšší, než byl celorepublikový průměr. Naopak nejnižší průměrná cena pro vodné $\left(34,10 \mathrm{Kč} / \mathrm{m}^{3}\right)$ byla v kraji Olomouckém. Nejnižší průměrná cena pro stočné $\left(28,80 \mathrm{Kč} / \mathrm{m}^{3}\right)$ byla v kraji Vysočina.

K nejvyššímu meziročnímu navyšování ceny vodného a stočného docházelo ve sledovaném období v kraji Plzeňském, a to průměrně o $3,80 \%$. Na druhém místě bylo hlavní město Praha s průměrným meziročním nárůstem $3,20 \%$. Naopak ve Zlínském kraji docházelo meziročně $\mathrm{k}$ nárůstu ceny průměrně $\mathrm{o} \quad 1,54 \quad \%$ a $\mathrm{v}$ kraji Moravskoslezském v průměru o $1,61 \%$.

Z provedené analýzy vývoje průměrných cen vodného a stočného ČR je patrné, že cena neustále stoupá. Dle šetření Českého statistického úřadu se cena vodného a stočného navyšovala i v roce 2020 . Tento trend bude nevyhnutelný i pro následující roky.

\section{ZÁVĚR}

Cílem tohoto článku bylo provést analýzu vývoje vodného a stočného v České republice. Zdrojem dat pro tento výzkum byl zvolen resortní portál Ministerstva zemědělství (MZe) eAGRI.cz. Výzkum byl proveden v časovém horizontu 10 let, tedy od ruku 2010 do roku 2019. Pro zhodnocení meziročních nárůstů nebo poklesů cen vodného a stočného byla zvolena metodika horizontální analýzy.

Z výzkumu je patrné, že cena vodného a stočného každým rokem narůstá. Za posledních 10 let (2010-2019) průměrná cena vodného a stočného vzrostla v ČR o $18.6 \mathrm{Kč} / \mathrm{m}^{3}$ bez DPH. Průměrně cena vodného a stočného ČR ve sledovaném období meziročně rostla o 3,28 \%. Z pohledu ceny vody byly ve sledovaném období nejlevnější Plzeňský kraj a kraj Vysočina, nejdražší byly kraje Ústecký a Liberecký. K nejvyššímu meziročnímu navyšování ceny vodného a stočného docházelo ve sledovaném období v kraji Plzeňském. Naopak nejnižší meziroční nárůst ceny vodného a stočného byl zaznamenán ve Zlínském kraji.

\section{Poděkování}

Tento článek byl zpracován v rámci projektu specifického výzkumu Vysokého učení technického FAST-S-217472 Management ekonomických procesů ve stavebnictví.

\section{Použité zdroje}

[1] Eagri.cz: Voda [online]. 2021 [cit. 2021-11-08]. Dostupné z: http://eagri.cz/public/web/mze/voda/vodovody-a-kanalizace/

[2] Český statistický úrad: Vodovody, kanalizace a vodní toky [online]. [cit. 2021-11-08]. Dostupné z: https://www.czso.cz/csu/czso/domov?p_p_id $=3 \& p \_p \_l i f e c y c l e=0 \& p \_p \_s t a t e=$ maximized\&p_p_mode $=$ view\&_3 struts_action $=\% 2 \mathrm{Fsearch} \% 2 \mathrm{Fsearch} \& \_3$ redirect $=\% 2 \mathrm{Fc} \% 2 \mathrm{Fportal} \% 2 \mathrm{Flayout} \% 3 \mathrm{Fp} 1$ id $\% 3 \mathrm{D} 201 \overline{3} 7706 \% \overline{2} 6 \mathrm{p} \_$___1_s_g_id\%3D0\&_3_keywords $=$vodovody $+\mathrm{a}+$ kanalizace \&_3 groupId=0

[3] Vyhláška č. 450/2009 Sb., kterou se provádí zákon č. 526/1990 Sb., o cenách, ve znění pozdějších předpisů

[4] Zákon č. 526/1990 Sb., o cenách, ve znění pozdějších předpisů

[5] Zákon č. 274/2001 Sb., o vodovodech a kanalizacích pro veřejnou potřebu a o změně některých zákonů (zákon o vodovodech a kanalizacích), ve znění pozdějších předpisů

[6] Vyhláška č. 428/2001 Sb., kterou se provádí zákon č. 274/2001 Sb., o vodovodech a kanalizacích pro veřejnou potřebu a o změně některých zákonů (zákon o vodovodech a kanalizacích)

[7] KEJSER, Anne. European attitudes to water pricing: Internalizing environmental and resource costs. Journal of Environmental Management [online]. London: Academic Press, 2016, 183, 453 [cit. 2021-04-04]. ISSN 03014797. Dostupné z: http://search.proquest.com/docview/1829748288/

[8] TABESH, Massoud a Soheila BEIGI. Water Pricing as an Economic Justification for Reducing NonRevenue Water (NRW) Projects. Āb va fāzilāb: majallah-i ‘ilmī, pizhūhishī [online]. Water and Wastewater Consulting Engineers Research Development, 2017, 28(1), 113-125 [cit. 2021-04-04]. 
ISSN 1024-5936. Dostupné z: doi:10.22093/wwj.2017.39480

[9] ASHOORI, Negin, David A DZOMBAK a Mitchell J SMALL. Identifying water price and population criteria for meeting future urban water demand targets. Journal of hydrology (Amsterdam) [online]. Elsevier B.V, 2017, 555, 547-556 [cit. 2021-04-04]. ISSN 0022-1694. Dostupné z: doi:10.1016/j.jhydrol.2017.10.047

[10] TSUR, Yacov. Optimal water pricing: Accounting for environmental externalities. Ecological economics [online]. Elsevier B.V, 2020, 170 [cit. 2021-04-04]. ISSN 0921-8009. Dostupné z: doi:10.1016/j.ecolecon.2019.106429

[11] FRIDMAN, Alla. Water pricing reform analysis: alternative scenarios. Journal of economic policy reform [online]. Routledge, 2015, 18(3), 258-266 [cit. 2021-04-04]. ISSN 1748-7870. Dostupné z: doi:10.1080/17487870.2015.1057510

[12] KANAKOUDIS, Vasilis a Konstantinos GONELAS. The Optimal Balance Point between NRW Reduction Measures, Full Water Costing and Water Pricing in Water Distribution Systems. Alternative Scenarios Forecasting the Kozani's WDS Optimal Balance Point. Procedia engineering [online]. Elsevier, 2015, 119(1), 1278-1287 [cit. 2021-04-04]. ISSN 1877-7058. Dostupné z: doi:10.1016/j.proeng.2015.08.996

[13] WAIT, Isaac W a William Adam PETRIE. Comparison of water pricing for publicly and privately owned water utilities in the United States. Water international [online]. Routledge, 2017, 42(8), 967-980 [cit. 2021-04-04]. ISSN 0250-8060. Dostupné z: doi:10.1080/02508060.2017.1406782. 